\title{
Mujeres y Cine. Estereotipos y Rebeliones
}

Andrea Pontoriero ${ }^{(1)}$

Resumen: En la década del 40 en la Argentina la historia parecía estar cambiando para las mujeres, se habían logrado derechos civiles y por primera vez iban a acceder al voto en 1947 pero cuando se analizan los discursos audiovisuales se encuentran representaciones de la mujer que se basan en estereotipos que marcan una resistencia a los cambios.

Las guerras del siglo XX al requerir de los hombres en el frente hicieron que las mujeres tuvieran que salir de sus hogares a ocuparse de trabajos que se asociaban a lo masculino, es por esto que en las revistas de la época se pueden encontrar imágenes de mujeres pilotos o soldadoras, actividades que siempre se asociaron a lo masculino. Sin embargo, al terminar la guerra, la tendencia fue hacer volver a la mujeres a la casa, con ese objetivo muchos de las producciones de comunicación de masa del momento se encargaron de promover esos mandatos desde las revistas, la radio y por supuesto el cine.

En los países como la Argentina que se mantuvieron en una "tercera posición” respecto de los conflictos bélicos y luego de la llamada guerra fría se vio una tendencia de incorporar a las mujeres al mundo del trabajo pero conservando una cierta separación respecto de los trabajos considerados masculinos o femeninos, sin embargo desde los medios masivos si bien se rescataba el mundo del trabajo como un valor positivo se recalcaba el hogar como el espacio femenino "natural".

Por otra parte, el peronismo, si bien promovió el voto femenino y desde la figura icónica de Eva se manifestaba un modelo de mujer fuerte, que trabajaba y ejercía el poder, desde la propuesta discursiva de su imagen siempre se la subsumía a la imagen de hombre fuerte que era Perón. Para el peronismo desde la estrategia discursiva se veía a la mujer como el "ángel del hogar" que sostenía la cohesión familiar. Se manifestaba así una tensión entre la interpelación a la participación y a la responsabilidad sobre lo público a través de la participación en el voto y la necesidad de mantener la integridad de la familia y el hogar. En este trabajo se realizará un análisis de cómo aparecen ciertos mandatos sociales dirigidos a las mujeres con el fin de mantener el status quo de las costumbres tradicionales que sometían a la mujer al ámbito doméstico, el cuidado de los niños y las tareas del hogar, todo ello materializado en la institución del matrimonio. Para esto se trabajarán un corpus de películas realizadas en las décadas de los 30 y 40 en donde, en apariencia, las mujeres que las protagonizan encarnan de alguna manera rebeliones contra el modelo imperante pero el relato y el formato cinematográfico se encargan de volver a ponerlas en el lugar tradicional de la esposa sumisa.

Se tomarán como casos testigos los films de Manuel Romero y de Carlos Hugo Christensen dado que dentro de la historia del cine una de las formas que toma la representación de la mujer en los años 40 es a través del llamado "cine de ingenuas", y se considera que 
este estereotipo llega su fin en los films de este último director en donde comienza a aparecer una erotización de los personajes femeninos.

Otra de las preguntas que nos guían en este trabajo y que recorrerán el análisis es si hay espacio para la rebelión, para el cambio en la construcción de los personajes femeninos, es decir la posibilidad de considerarlas como sujetos de la acción capaces de llevar adelante un proyecto y de realizar sus deseos, dado que es notable cuando se revisan los títulos del período el alto porcentaje de films que aluden a los personajes femeninos como eje de la acción.

Palabras clave: Cine - Mujer - Género - Estereotipos - Clase Media - Heroína - cine de ingenuas - Rebelión - Sociedad.

[Resúmenes en inglés y portugués en las páginas 181-182]

(1) Andrea Pontoriero. Maestría en Gestión del Diseño (UP, 2017). Licenciada en Artes (UBA, 1998). Profesora de Enseñanza Media y Superior en Artes (UBA, 1998). Profesora y Coordinadora del Área de Teatro Espectáculo y Música de la Facultad de Diseño y Comunicación de la Universidad de Palermo desde 2014. Es actriz y directora teatral. Entre sus creaciones se destaca Prueba de Amor de Roberto Arlt. Obtuvo premio como "Actriz Revelación" por su actuación en La gaviota de Chejov. Ha presentado sus trabajos académicos en numerosos Congresos y Jornadas Nacionales e Internacionales.

\section{Las mujeres en el cine en los años 30 y 40}

El cine constituía uno de los entretenimientos más importantes de la clase trabajadora de mitad de siglo. Uno de los cambios más importantes, a nivel social, que se dieron en el siglo XX que fue el surgimiento de la clase media en la Argentina. Según Adamovsky la clase media es difícil de diferenciar, no es una "cosa directamente observable" (p. 11) y además no tiene una identidad de clase por lo tanto tiene que ver más con una imagen mental. Es en la construcción de esta imagen mental a través de las representaciones que se hacen de ella en los films y particularmente de las imágenes de mujeres y los estereotipos que se utilizan para configurar la "identidad femenina" en donde hará foco este trabajo.

Respecto del rol social del cine, Dora Barrancos (2019) dice que en el período que estamos tratando, el cine formaba parte de uno de los modelos para soñar y ser, junto con el folletín y la radio porque si bien el teatro también tenía importancia no llegaba a la masividad de estos medios. 
Ir al cine era la distracción predilecta de hombres y mujeres que vivían de salarios y esta lealtad al medio se profundizó aún más en los años cuarenta, cuando la cinematografía nacional alcanzó un punto singular de madurez.

Las jóvenes que se cansaban en trabajos repetitivos y extenuantes o matizados por lo heterogéneo, penosos o de mayor significación social, disciplinantes y al mismo tiempo con márgenes para la sociabilidad, asediadas sexualmente $\mathrm{o}$ con menores riesgos o más protegidas, encontraron en el cine un vehículo de descanso, de esparcimiento, de proyección de deseos y erotización, y también modelos para "ser". (Barrancos, p. 418)

Respecto de la representación de las mujeres en el cine, en su tesis de doctorado, la autora María Inés Conde (2009) especifica los títulos cinematográficos que se refieren a mujeres: "las películas suman un total de 176 (lo que constituye el 20\% de la producción total del período)" (Conde, p. 122) Se ve en estas cifras el interés de la industria cinematográfica de poner a la mujer en el centro del relato, pero la cuestión en estas propuestas es: ¿el hecho de estar en el centro las constituye en sujetos, en heroínas que llevan adelante la acción?

La exaltación de las figuras femeninas del cine, modelos de afirmación personal y de erotismo, promovida por la industria cultural, tuvo eficaz apropiación por las propias mujeres, que querían imitarlas, y esto se debe a una subjetividad femenina todavía en tránsito hacia el acontecimiento del deseo, mientras pesaban las obligaciones y los estereotipos, al punto de ligar a esa suerte la propia experiencia de la sexualidad genital (Barrancos, p. 418)

Ahora bien la forma en que funciona la representación de las mujeres en estos films responden a estereotipos que no tienen un origen en esta época, sino que funcionan como una imagen de cómo "son" las mujeres "en general", es decir intentan ser una universalización de la imagen femenina y un espejo en donde las mujeres puedan verse y sentirse identificadas. Figari (2011) plantea que en el Romanticismo moderno europeo aparecen dos estereotipos de mujeres: "la mujer ángel" y "la mujer vampiro". Ambas están en función del hombre: la primera, fortalece el alma y el hombre se siente Dios a partir de ella, y la segunda, es una seductora de hombres ingenuos y la responsable de que el hombre caiga en la perdición. Este dualismo en los personajes femeninos se trabaja desde el romanticismo del siglo XIX y sigue siendo efectivo en varios productos culturales del siglo XX. Sin embargo, en el período que estamos estudiando, dado el surgimiento de las clases medias, el problema de la modernización y la inserción laboral de las mujeres que hacen que se salga de su dominio doméstico, los estereotipos femeninos se los trabaja enmarcándolos en el campo de lo familiar que funciona como el espacio a donde hay que devolver a la mujeres. Podemos ver en el cine de la época que muchos autores recurren a la tipología de "cine de ingenuas".

De la mano de Múgica irrumpió hacia principio de los años 40 un nuevo universo social dentro de los relatos fílmicos, que se caracterizó en los primeros 
años por un modelo pocas veces estudiado en la historiografía nacional: el cine de ingenuas (Kelly Hopfenblatt, p 3)

Dentro de este modelo, el autor ve aquí como el cine se hace cargo de la representación de la familia burguesa en contraposición a la década anterior en donde aparecían rasgos de criollismo y de sainete así como elementos populares como el tango y el género chico criollo. Uno de los hitos en este proceso de aburguesamiento es el film de Fracisco Mugica Así es la vida (1939). Kelly Hopfenblatt (2014) contrapone este modelo aburguesado de Mugica al modelo de Romero que basaba sus argumentos en personajes populares como Catita. Mugica en cambio introdujo otras figuras y personajes que exaltaban a la burguesía idealizando de este modo a las clases tradicionales cuyos valores estaban siendo cuestionados por la modernización de las costumbres tanto en lo que refiere a lo sexual, como a lo civil y lo laboral. El autor hace un análisis exhaustivo de cómo se configura lo público y lo privado en este tipo de cine, marcando cómo el espacio de la familia, el hogar familiar es planteado y trabajado como un espacio de ensoñación y cómo el comedor funciona para entender la dinámica de la familia patriarcal donde el pater familias ocupa la cabecera de la mesa, una de las frases que marcaron el rol del padre como regulador de las relaciones familiares es la del protagonista de Así es la vida cuando dice "hay que agrandar la mesa". El comedor funcionaría como un espacio público dentro de la casa en donde pueden acceder invitados y los dormitorios como espacios privados y de intimidad familiar.

Pero para llegar a la conformación de la familia, es necesario en el nomos (Berger, 1969) de la sociedad argentina del siglo XX que primero se produzca el matrimonio. En este ensayo vamos a abordar cuatro films: dos de Romero y dos de Christensen en donde se pivotea por el tema del matrimonio. También se indagará cómo la rebeldía de algunas mujeres frente al mandato social de formar una familia burguesa está contemplado pero encausado en la "loca juventud" como una cuestión temporal, pasajera, que siempre termina en el matrimonio.

\section{Las pitucas y las trabajadoras}

Vamos a comenzar nuestro recorrido por el film de Romero (1938) Mujeres que trabajan. Si nos manejamos por lo dicho anteriormente el momento preciso del pasaje entre los films que hacen foco en lo popular y los que marcan el aburgesamiento estaría dado en 1939 con Así es la vida, de Mugica, sin embargo en el film de Romero, Mujeres que trabajan de 1938 podemos ver cómo se muestra un cambio en la forma de considerar a las clases altas y su posibilidad de ganar la redención si adoptan los valores positivos de la cultura del trabajo.

La película abre con un plano que nos ubica en una Boite. El montaje, nos muestra luego imágenes de piernas bailando, intercaladas con planos de un reloj que va mostrando el avance del tiempo: 4 hs, 6 hs. 7 hs en la madrugada, e imágenes de mozos agotados, músicos dormidos (personajes que trabajan para sostener la juerga de los "niños ricos") Desde el punto de vista de lo formal, además de utilizar el montaje de la forma que plantea 
Eisenstein (1991), como una forma de realizar un planteo ideológico, hay una particularidad en estas tomas y es que las imágenes están torcidas, la cámara fue ubicada a propósito para, desde el encuadre, mostrar la posición del autor respecto de lo que sucede como algo negativo, que está torcido y debe ser enderezado: la moral, de las clases altas, pitucas, holgazanas debe transformarse en la moral del orgullo del trabajo y el esfuerzo. Este es el trayecto que el personaje de Mecha Ortíz, la "niña rica holgazana", realizará a lo largo de la película. Para exponer esta tesis, Romero, a través del recurso del montaje, muestra a los ricos, vestidos lujosamente, borrachos que se niegan a cortar la fiesta e inmediatamente después los contrasta con un grupo de mujeres en una pensión que temprano a la mañana están arregladas para salir a trabajar, esperando que la dueña de la pensión les prepare el desayuno. Este tiempo de espera del desayuno, Romero lo aprovecha narrativamente para caracterizar a cada una de las muchachas: se la ve a Catita (personaje icónico de Nini Marshall) que está de novia con el único personaje varón que vive en la pensión que es el chofer de la "niña" hija de un banquero rico, y que se distingue de las otras por su manera de hablar tomando modismos populares. El resto de las muchachas son muy parecidas en cuanto a sus vestuarios y peinados y básicamente se las caracteriza como soñadoras que saben que el momento en el que están, es transitorio: "Yo sueño con el cine, que me caso con Robert Tailor", aquí aparece esta idea del cine como la máquina de los sueños de la que hablaba Barrancos y que sostenía todo el aparato hollywoodense de la época. Llama la atención en este grupo, un personaje femenino que tiene vestuario, peinado y caracterización muy similar al resto pero luce una corbata, claramente una indumentaria masculina. Este personaje les hace saber a las otras muchachas que todo lo que dicen son tonterías y que sus sueños nunca se realizarán. En ese momento vemos que está leyendo un libro de Marx.

En su tesis Cinderella from the Pampas en donde analiza la figura de Evita, la autora Valeria Alacino (2017) explica cómo se demonizaba la figura de las mujeres luchadoras sobre todo anarquistas y socialistas y se las denigraba por "feas" y "masculinas", no es el caso de este personaje que responde a los cánones de belleza vigentes en la época y prácticamente no se distingue de las demás salvo por el rasgo de masculinidad que le da la corbata y por sus discursos antisistema. La "rebelde" es catalogada por las demás como una amargada. Sin embargo toda esta "aparente" rebeldía que manifiesta la "marxista" es demolida al final de la película cuando, ante el casamiento de la protagonista, dice suspirando: "Si yo hubiese encontrado un amor, no leería tanto".

Inmediatamente después de estas escenas de presentación y contraste de ambas clases sociales, los pitucos y los trabajadores, el director las junta en una lechería, un espacio para desayunar en donde se encontraban las trabajadoras antes de entrar a sus puestos de trabajo. A este espacio hace entrar a los ricos que sin dormir, luego de estar de fiesta toda la noche, van a desayunar. La protagonista encarnada por Mecha Ortíz, brinda: "Nosotros los holgazanes, levantamos nuestras copas por las mujeres que trabajan" y luego de esta provocación, se acerca a darles plata que, por supuesto, las trabajadoras no aceptan porque tienen dignidad, a lo que el personaje de Mecha Ortíz contesta: "Debe ser interesante ser pobre y orgullosa como ustedes". Algo que va a confirmar en carne propia ya que en ese momento y siguiendo la metábole, o cambio de fortuna del relato clásico aristotélico, acontece: su padre banquero muere y la deja en la pobreza total y termina viviendo en la 
pensión de las "mujeres que trabajan": "Es un castigo, me burlaba de la pobreza y ahora yo soy pobre". En este trayecto, el personaje femenino de la niña rica caída en desgracia, va a aprender que se puede trabajar para valerse por sí misma, que las muchachas trabajadoras se ayudan entre sí, pero sobre todo que la única manera de mantener el honor y una posición aceptada socialmente, no importa si se es rica o pobre, es a través del casamiento. Las mujeres solas no son respetadas y es imprescindible cuidarse del qué dirán.

Las mujeres que trabajan lo hacen en una tienda multi rubro, típicas de la época, en este caso en particular, de un hombre llamado Stanley. Una de ellas logra ser su secretaria. A lo largo del film vemos cómo incluso estar sola como secretaria dentro de la oficina de este jefe inescrupuloso, es peligroso. Stanley se aprovecha de su poder para seducir a mujeres "ingenuas". Ilusionó a esta muchacha con el casamiento y la dejó embarazada. Aquí es interesante ver cuáles son las soluciones que se proponen a este "problema": la única salida socialmente aceptable es que Stanley se case con la muchacha que dejó embarazada, no importa que haya sido un abuso de poder, no importa que la desprecie. Pero esto no sucede, lo único que ofrece Stanley para "reparar" su error es dinero, pero como la muchacha es muy "orgullosa", no lo acepta. Aquí hay algo interesante respecto del grupo de mujeres de la pensión y compañeras de trabajo: deciden organizarse y hacer una "vaquita" entre todas para que ella pueda mantenerse y mantener a su bebé sin tener que volver a trabajar con ese hombre que la denigró, y también se organizan para cuidar al recién nacido. Se ve aquí un rasgo positivo de las trabajadoras que es la solidaridad y la organización para cuidar y cuidarse. Pero el film sostiene el mensaje conservador respecto al orden social y al lugar de las mujeres, el matrimonio es el final del trayecto de cualquier rebeldía o anomalía que pueda suceder, cada uno ocupa su lugar: la hija del banquero se casa con su novio de clase alta que juega al polo pero dejando de lado los disvalores de la holgazanería y la diversión de los tilingos que quedan enmarcados en la loca juventud y tomando los valores del esfuerzo y el trabajo que aprendió a fuerza de convivir con las mujeres que trabajan y de hacer la experiencia de valerse por sí misma a través del esfuerzo. Es interesante cómo en el casamiento se mezcla el ritual religioso con el civil y aparece el juez leyendo el código y recitándole todas las obligaciones a los cónyuges haciendo hincapié en la fidelidad.

\section{Estudiantes rebeldes e ingenuas}

Muchachas que estudian es el título de un film del mismo director, Manuel Romero, un año posterior al estudiado en el apartado anterior, 1939. Pongámonos en contexto, respecto a los estudios universitarios, las mujeres tuvieron muchas dificultades para acceder a la Universidad, no sólo en nuestro país sino en el mundo ya que se consideraba que las mujeres no tenían capacidad para las ciencias dado que dentro de los estereotipos que se manejaban, la razón era el espacio de lo masculino y el sentimiento era el ámbito de lo femenino.

En verdad, para el caso de Oxford, solo en la década de 1920 se posibilitó la formación completa en el ciclo de graduación, pero hubo que esperar la fina- 
lización de la Segunda Gran Guerra para que las mujeres obtuvieran idéntica titulación que sus compañeros varones. En la mayoría de los casos en que se franquearon las puertas de la enseñanza superior -descontando las artes y las letras que las admitieron aunque tampoco de manera masiva-, las opciones de las muchachas deseosas de estudiar fueron la práctica obstétrica y la medicina. (Barranco, p. 255)

El acceso a los estudios de todos modos no implicaba necesariamente que luego las mujeres pudiesen dedicarse a su vida profesional ya que el mandato social les exigía muy fuertemente ser las responsables del cuidado del hogar y de los niños.

Sin duda, una marca de género de buena parte del siglo XX consistió en que a menudo las funciones reproductivas absorbieran por completo a las vocaciones profesionales. Se constata que muchas universitarias, hasta bien avanzadas las décadas, solían dejar sus diplomas colgados de las paredes, dedicándose a las labores domésticas y a la crianza de los hijos. (Barranco, p. 259)

Veamos cómo aparece el tema del estudio en el film de Romero Muchachas que estudian (1939). Nuevamente en las secuencia de apertura, donde se establece el contrato de lectura del film (Eco, 1991), el director, deja su tesis planteada. La cámara nos ubica en un espacio: Club femenino. Y un cartel que indica: "Hoy discusión en Libre Tribuna. Tema: El matrimonio y la mujer que estudia”. Ahí toma la palabra la protagonista del film quien asegura: "Una vida de estudio no necesita amor. El matrimonio hace de la mujer una esclava y la convierte en un ser inferior al hombre, su dominador secular. Hermanas estudiantes: Seguid el ejemplo mío y el de mis amigas aquí presentes. Estableced una comunidad femenina y tratad de ser camaradas de los hombres. ¿Hay algo más hermoso que la amistad entre un hombre y una mujer? ¿Hay algo más fructífero que la colaboración de dos seres inteligentes que viven para la ciencia? El matrimonio destruye su potencia intelectual." Es interesante cómo este discurso está en boca de una mujer e iguala a los hombres y mujeres en su capacidad intelectual. El contenido y la visión del matrimonio se acercan a las visiones de las anarquistas quienes militaban por un mundo sin patrón, ni patria, ni marido. Y llama la atención el término camaradas que era utilizado por los comunistas. También se destaca que frente a este discurso por la igualdad de los sexos y la capacidad de las mujeres para dedicarse a la ciencia, colocan a un profesor (en masculino) de poesía quien dice "sin amor no hay genio". Este planteamiento claramente antisistema en donde los roles masculinos y femeninos están invertidos, termina siendo efectivamente conservador porque luego del trayecto del film este personaje femenino disruptivo se casa con su profesor de biología con el que investigaba y al que consideraba su "camarada". Una vez más hay lugar en estos films para las manifestaciones de discursos alternativos pero a estos se los enmarca en un período de transición, antes de que estas muchachas asuman el lugar que tienen que ocupar en la sociedad, en una familia burguesa bien constituida en donde el marido es el que establece el orden y el "dueño" de la mujer. El profesor le dice una vez casados: "ahora eres mía, de verdad". En ese trayecto que va de la rebelión juvenil a la madurez del matrimonio, el film de Romero nos ofrece varias apreciaciones sobre los 
estereotipos femeninos y cómo estas ambiciones de profesionalismo de las mujeres son anomalías del sistema que están acotadas a un tiempo y espacios transitorios antes del gran momento de cambio y de entrada a lo social que es el matrimonio. Aparece también el tema de la diferencia de clases y las ganas de la mujer de clase baja de acceder al lujo "si yo tuviese esa plata cualquier día iba a estudiar". El estudio también está asociado a la necesidad, pero si una logra casarse con un hombre rico que puede proveer, el estudio deja de ser "necesario", y entonces pasa lo que manifiesta Barranco (2019) que muchos títulos quedan colgados porque las mujeres se dedican al cuidado de la casa y los niños. Se ve claramente en el film incluso que el poder mantenerse depende de los hombres porque aunque el personaje femenino estudia medicina no ve su futuro prometedor porque va a ser la esposa de un hombre pobre, en un mísero pueblo. A ella no se le ocurre pensar que ella puede ser sostén económico de la familia.

Otro tema es el colegio, acá las muchachas aún son adolescentes y entonces todavía hay lugar para la rebeldía antes del momento de formar familia. Respecto de este tema hay dos films de Christensen asociados: La pequeña señora de Pérez (1943) y La señora de Pérez se divorcia (1945), ambos pertenecientes al sistema de estudios argentino: Luminton y ambos protagonizados por Mirta Legrand. Aquí el tema de la protagonista es importante porque se trata de una estrella del star system local que responde al estereotipo de la ingenua y de igual modo que sucede en el hollywoodense, al decir de Edgar Morin (1966) la estrella carga no sólo con el personaje que representa en el film sino con toda la simbología que se fue construyendo a lo largo de su historia como tal.

Ya nos enteramos en los títulos de La pequeña señora de Perez que asistiremos a un relato de "amor romántico" ya que los mismos se desarrollan sobre una imagen de Cupido. Luego siguiendo la práctica de la época de orientarnos en el espacio, la cámara nos ubica en el Liceo 1, se ve el patio y a las señoritas de guardapolvo blanco, luego vemos los pupitres en el aula y al profesor ubicado en el podio. Se nos cuenta a través de estas imágenes cómo funciona el modelo educativo del momento: en los liceos solo había "señoritas" que estudiaban y el lugar del saber estaba ocupado por profesores hombres que ocupaban un lugar distinguido, separado y por encima de las estudiantes. Frente a este orden educativo, nos trasladamos a un interior en una casa tipo mansión, en un dormitorio con una cruz de gran tamaño sobre la cama del personaje de Mirta Legrand que con 17 años se hace la enferma para no ir a clases. En sus propias palabras: se hizo la rabona. Esta es la "rebeldía" de la señorita que no tiene muchas luces para el estudio pero todo el tiempo piensa en el amor. Se enamora del doctor, que por el sistema de enredos del film también será un profesor invitado de la escuela y "obviamente" para poder consumar el deseo de ambos, se casan. Remarco el obviamente porque en el film nadie se escandaliza de que un hombre mayor tenga amoríos con una menor de 17 años, justamente porque se casan y eso parece validar cualquier relación amorosa. El matrimonio va a vivir a un departamento de clase media pero la familia acomodada de la "niña" le "regala" la criada para que la asista.

¿Qué hacen las señoras cuando están casadas? Se pregunta la jovencita casada de 17 años. Respuesta: dormir hasta el mediodía. Salir de compras. Ir a la peluquería. Como es una joven casada ya no "necesita" ir a la escuela. Entra en sociedad, le cambian el vestuario y recibe invitaciones, pero ella es pequeña y extraña el liceo. Pide volver pero el marido, le dice: ¡No necesitás nada! Le da un beso y le dice que no piense más en el Liceo. Pero ella, 
como es "rebelde" se hace pasar por huérfana y vuelve al colegio con un nombre falso, mientras su marido trabaja y no está en casa. Lleva así una doble vida: por un lado es una colegiala durante el día y por el otro cumple con sus obligaciones sociales de la esposa. Hay una escena donde esta vida de fiesta entra en conflicto con sus estudios. Aquí aparece nuevamente el recurso de la cámara torcida. Se suceden imágenes de relojes mostrando cómo pasa la hora y cómo el alcohol la lleva a un lugar de ensoñación, a un mundo imaginario en donde hay relojes y personajes bailando, algunos sublimes que aluden a princesas y príncipes bailando clásico y recreando a través del ballet personajes enamorados y otros grotescos y amenazantes que irrumpen y la asustan. La escena del sueño es cortada por el reloj despertador que le marca la hora de ir al examen. La película muestra toda una serie de procedimientos de quid pro quo de dan vueltas sobre la posibilidad de infidelidad de la señora de Perez pero ella es una "ingenua", sólo quiere estudiar y estar con su marido que parecen ser dos mundos incompatibles, pero el amor todo lo hace posible. La película cierra con una reconciliación en donde dando lección la señora Perez, en la escuela, frente a su profesor, marido, doctor, dice: "El corazón es esa pequeña alacena donde guardamos nuestros deseos más dulces, cuando encontramos a alguien que se parece a esos sueños, el corazón se hace tan enorme que invade por completo los pensamientos" Y su marido, profesor, doctor Pérez le dice: "Aprobada pequeña señora de Perez". La historia, la música la iluminación acompañan esta visión del amor romántico, los sueños del príncipe azul y la palabra del hombre ubicando a la chica en su lugar. Si bien esto es así algunas de las cuestiones mencionadas reflejan una cierta crítica a lo que se esperaba de las mujeres casadas, sus vidas vacías sin nada que hacer y cómo sus sueños terminaban ni bien se casaban. Esta infelicidad que provoca el matrimonio para las mujeres va a ser tratada a partir de estos mismos personajes en el film La señora Pérez se divorcia (1945).

La aparición de la palabra divorcio en el título de un film marca una inquietud de la época, históricamente este tema fue resuelto recién en la década de los 80 , pero esto no quiere decir que la sociedad no practicara la separación de hecho y que esto no generase problemas familiares respecto a las herencias y los derechos de los hijos. Durante el peronismo se sancionó una ley de divorcio vincular que tuvo vigencia desde el $1^{\circ}$ de abril de 1955 hasta el $1^{\circ}$ de marzo de1956. En su trabajo sobre la Ley del divorcio vincular de 1954 los autores Marta Camuffo y Rubén Lasso (2010) realizan un estudio de cómo el peronismo sanciona esta ley preguntándose si hay una confrontación respecto de este tema con la Iglesia Católica o se trata de una política social acorde con la propuesta peronista. Dentro de este análisis, los autores plantean que hay una tensión entre el pedido de actuación de la mujer en la esfera pública que incluía el voto femenino, por un lado, y la mujer como el centro del hogar y de la familia, por el otro. Dado que el peronismo centraba su proyecto político no en el individuo sino en la familia como el centro de la estructura social tenía interés por darle importancia a los matrimonios, a las familias y por ende, solucionar los problemas ocasionados por los hijos habidos en situaciones extra matrimoniales. En este el marco el gobierno de Perón realiza un censo para medir la cantidad de divorcios en 1947.

El clima de época en relación con la problemática femenina se observa en la prensa y en el cine: a fines de la década de 1940, Noticias Gráficas publica entrevistas realizadas a autoridades de las diversas instituciones que agrupan 
a los profesionales del derecho, mostrando por unanimidad la necesidad de legislar el divorcio. Por su parte, y a modo de ejemplo, a mediados de la década siguiente, la película "Mujeres casadas" pone de manifiesto diversas situaciones de subordinación de la esposa respecto de su cónyuge. En la concepción organicista de Perón, la sociedad, en tanto cuerpo, estaba constituida por unidades mínimas que no eran los individuos sino las familias, como reza la Doctrina Nacional: "La familia es la célula básica de la organización social. Como tal debe ser protegida por el Estado mediante el desarrollo de los derechos especiales que consagra el artículo 37 de la Constitución Nacional” (Doctrina, 1954: 33) (Camuffo, p. 4)

Como se ve, el tema involucraba interés desde los ámbitos públicos y de la legislación como una necesidad social de hacerse cargo del tema y los medios y los discursos ficcionales también se ocupaban de estas cuestiones. Veamos cómo en 1945, la película de Chistensen trabaja el tema.

Nuevamente, en esta película se instaura el contrato de lectura $(E c o, 1991)$ en sus primeros planos. Recordemos que estos personajes ya habían aparecido en La pequeña señora de Pérez (1943) pero este nuevo filim puede ser visto también como una unidad de sentido. El director nos muestra un plano con un cartel: Dr. Perez, el montaje nos lleva a un plano de piernas de mujeres, sentadas esperando, las piernas se mueven connotando nerviosismo. La cámara entonces focaliza en una mujer en particular que llama la atención por su actitud y su vestuario respecto de las demás: se encuadra dentro del estereotipo de la femme fatale, la mujer vampiro de la que habla Figari (2011) que seduce y provoca la perdición de los hombres y que se contrapone frente a la figura de la esposa, ingenua, "mujer ángel”, encarnada por Mirta Legrand, que es etérea e inmaculada. En esta contraposición Christensen pone en juego su tesis en este film: el matrimonio está en peligro porque este médico tiene la sala atestada de mujeres, es decir trabaja mucho y no "atiende" a su esposa, además de estar en peligro por las ambiciones y la seducción de la "mujer vampiro" que no tiene escrúpulos para seducirlo. El espacio del matrimonio es inmaculado: se muestra como la pareja duerme en camas separadas con una cruz de enormes proporciones colgada en la pared entre ambas camas, que vigila y protege al matrimonio. El conflicto se desata cuando la esposa pesca a su marido en el momento en el que "la vampira" lo besa, y ella compungida se va a llorar a la casa de la mamá y el papá. A pesar de que llora como un bebé, le dice a su papá que no la llame "nena". Es entonces que aparece el tema del divorcio, pero sus padres están en desacuerdo porque el divorcio es inmoral. "Solo las locas piensan en el divorcio" dice el padre. "Pensá en nosotros", dice la madre. Luego, en el film suceden una serie de peripecias destinadas a que la mujer ponga celoso a su marido hasta que él le dice "Te devuelvo la libertad" es decir, él le da la posibilidad de divorciarse. Pero obviamente esto no queda así, la reconciliación se produce porque él la hace vivir situaciones prohibidas para una mujer de bien, la lleva a una boite, a gabinetes reservados que según se expresa en la película "son un atentado contra la moral", ahí se sueltan, se relajan, beben, bailan, se ríen y elipsis. Toda situación que alude a lo sexual es tratada de esta manera en los films de la época. Resulta interesante, cómo el film se hace cargo de escenas eróticas, de la hipocresía de los hombres que tienen aventuras "reservadas" en espacios diseñados para 
mantener las apariencias porque se realizan en clandestinidad, y cómo estas situaciones están naturalizadas. Pero al final se vuelve al orden de una forma intempestiva y original que rompe con todas las reglas del relato cinematográfico vigente. La reconciliación termina de realizarse en un juzgado, frente a un juez de divorcio, el matrimonio decide seguir junto y entonces el juez rompe la diégesis, y con su rostro en un primer plano, dirigiéndose a cámara, dice: "Sí, señoras y señores, la felicidad del matrimonio consiste en que marido y mujer vivan una aventura diferente, el uno con el otro" (mirando a cámara y con el dedo acusador, como dirigiéndose a alguien que se encuentra en la platea) Sí, señor, no se ría. Anímese y bese a su mujer en el cine. ¡Le prometo cerrar los ojos! Fin.

Esta forma de interpelar al público, dándole una orden, muestra en forma exagerada lo que a mi criterio es un rasgo de los films de este momento, los mensajes son redundantes y prescriptivos, se debe hacer lo imposible por llegar al matrimonio y mantenerlo como regulador de la sociedad, como el núcleo de la sociedad y de la familia, y cumplir con los roles establecidos para hombres y mujeres dentro del mismo. El autor Alejandro Kelly Hopfenblatt (2014) analiza como

el cine de ingenuas no rechazó la modernidad sino que buscó adaptarla a los valores tradicionales, tomando sus elementos positivos, neutralizándolos y asimilándolos. Exaltando la familia como último reducto de resistencia frente a las amenazas desequilibrantes del exterior, se proponía un mundo donde el amor y el honor sirvieran como filtro para asegurar que, si la sociedad debía cambiar, al menos los valores fundamentales de los sectores en retirada aseguraran su pervivencia (Kelly Hopfenblatt, p 1)

y uno de estos valores fundamentales era proteger la idea de familia convencional y el matrimonio como único camino legítimo para llegar a ella.

\section{Algunas reflexiones finales}

Una de las preguntas que nos hacíamos al comienzo de este ensayo tenía que ver con el interés de la industria cinematográfica de poner a la mujer en el centro del relato, y si este hecho implicaba que por estar en el centro las mujeres fueran sujetos del relato, heroínas que llevan adelante la acción. Desde lo que acabamos de analizar vemos que los deseos de las mujeres que rompen con la mirada tradicional de la familia burguesa bien constituida a través del matrimonio tienen desarrollo pero le los ubica en un período delimitado: "la juventud", la "adolescencia", donde esos deseos se manifiestan, a veces como "sueños" que tienen que ver con el desarrollo propio, como el deseo de estudiar o de dedicarse a la ciencia, o de trabajar y tener una independencia económica. También se accede a personajes femeninos que tienen la fuerza de oponerse al imperativo social del momento, incluso con discursos encendidos y fundamentados como en el caso de la protagonista de Muchachas que estudian, pero, el relato siempre termina de la misma manera: celebrando el matrimonio. Sin embargo, aunque los momentos de rebeldía estén enmarcados, estos 
discursos que focalizan en la rebeldía, trabajan en el imaginario social para habilitar el poder imaginar mundos posibles. Estas rebeldías juveniles tendrán que esperar un par de décadas para transformar los hábitos sociales.

Se ve por otro lado el rescate de ciertas prácticas de lo que en nuestra actualidad se llama sororidad entre mujeres: esta idea de decidir criar un bebé entre todas para socializar el esfuerzo y contener el desprecio que el sentido común del momento tenía por las madres solteras y los niños "de padre desconocido", muestra también la posibilidad de salidas colectivas que tendrán un protagonismo concluyente en el futuro para poder lograr cambios.

\section{Bibliografía}

Aristóteles (1979) Poética. Madrid: Aguilar

Adamovsky, Ezequiel (2009) Historia de la clase media argentina. Apogeo y decadencia de una ilusión (1919-2003). Buenos Aires. Planeta

Alacino Valeria (2017) Cinderella from the Pampas. Tesis. Buenos Aires. Universidad de San Andrés.

Barrancos, Dora (2019) Devenir feminista. Una trayectoria político-intelectual. Buenos Aires. Editorial de la Facultad de Filosofía y Letras.

Berger, P. (1969) El dosel sagrado. Elementos para una sociología de la religión. Buenos Aires. Amorrortu

Campbell, Josheph (1959) El héroe de las mil caras. México. FCE.

(1991) El poder del mito. Barcelona. EMECE.

(2000) Los mitos en el tiempo. Buenos Aires. EMECE

Camuffo, Marta Ángela; Lasso, Rubén (2010). «El divorcio vincular de 1954: ¿confrontación con la Iglesia Católica o política social acorde al pensamiento peronista?». En II Congreso de Estudios sobre el Peronismo, Red de Estudios sobre el Peronismo, ISSN 1852-0731. Recuperado de http://redesperonismo.org/articulo/el-divorcio-vincular-de1954-confrontacion-con-la-iglesia-catolica-o-politica-social-acorde-al-pensamientoperonista/ [último acceso: 23/12/20]

Conde, Mariana Inés (2009) Martes, día de damas. Mujeres y cine en la Argentina, 19331955. Buenos Aires. Tesis de Doctorardo en Ciencias Sociales (UBA).

De Lauretis, Teresa (1992): Alicia ya no. Feminismo, Semiótica, Cine, Madrid, Cátedra.

Eco, U. (1991) Lector in fabula. Barcelona: Lumen

Eisensteien, Serguei (1991) Hacia una teoría del montaje. Barcelona. Paidós

Figari, María Rosa (2011) El romanticismo rioplatense en la construcción discursiva de la Nación en Figari, Hovannessian, Sacchetti Voces y miradas femeninas. Cultura Arte y Género. Buenos Aires. Editorial Borromeo

Figari, Hovannessian, Sacchetti (2007) Otra infamia en la década: Mujeres, disciplinamiento y resistencias (1930-1945), Discursividades: Nuevos sujetos discursivos en el cine de Manuel Romero, ¿Doxa o episteme? Representaciones de la filiación en el cine nacional 19381949 en 10 Estudios sobre Mujeres. Buenos Aires: Editorial Sarquís.

Kelly Hopfenblatt, Alejandro (2014) Un modelo de representación para la burguesía: La 
reformulación de identidades y espacios en el cine de ingenuas en Imagofagia. Revista de la Asociación Argentina de Estudios de Cine y Audiovisual en www.asaeca.org/imagofagia No10 2014 ISSN 18529550

Kelly Hopfenblatt, Alejandro (2013) Hacia un cine de clase media: contexto de surgimiento y consolidación de la comedia sofisticada en el cine argentino en XIV Jornadas Interescuelas/Departamentos de Historia. Departamento de Historia de la Facultad de Filosofía y Letras. Universidad Nacional de Cuyo, Mendoza, 2013. Disponible en https://www. aacademica.org/000-010/297

Morin, Edgar (1966) Las estrellas del cine. Buenos Aires. EUDEBA

Mulvey, Laura [1975] (2007): "El placer visual y el cine narrativo", en: Karen

Cordero Reiman e India Sáenz (comp.) Crítica feminista en la teoría e historia del arte, México, Universidad Iberoamericana.

Suriano, Juan (2001) Anarquistas: Cultura y Politica Libertaria en Buenos Aires, 1890-1910. Buenos Aires. Manantial

\section{Filmografía}

Christensen, Carlos Hugo (1944) La pequeña señora de Pérez. Buenos Aires. Estudios Lumiton. c/Mirtha Legrand y Juan Carlos Thorry

Christensen, Carlos Hugo (1944) La señora de Pérez se divorcia. Buenos Aires. Estudios Lumiton. c/Mirtha Legrand y Juan Carlos Thorry

Mugica, Francisco (1939) Así es la vida. Buenos Aires. Estudios Lumiton. c/Enrique Muiño, Enrique Serrano, Sabina Olmos

Romero, Manuel (1938) Mujeres que trabajan. Buenos Aires. Estudios Lumiton c/Mecha Ortiz, Tito Lusiardo, Niní Marshall, Pepita Serrador, Alicia barrié, Fernando Borel, Sabina Olmos

Romero, Manuel (1939) Muchachas que estudian. Buenos Aires. Estudios Lumiton. con Sofía Bozán, Enrique Serrano, Alicia Vignoli, Delia Garcés, Pepita Serrador .

\section{Women and Cinema. Stereotypes and Rebellions}

Abstract: In this work, an analysis will be carried out of how women are called to tradition and status quo, by social mandates which suppose women duties are related to the domestic sphere, childcare and household chores, all this materialized in the institution of marriage. For this, a corpus of films made in the 30s and 40s will be worked on where, apparently, the women who star in them somehow embody rebellions against the prevailing model, but the story and the cinematographic format are responsible for putting them back. in the traditional place of the submissive wife. 
Keywords: Cinema - Woman - Gender - Stereotypes - Middle Class - Heroine - "ingenuas" films - Rebellion - Society.

\section{Mulheres e Cinema. Estereótipos e rebeliões}

Resumo: Neste trabalho, será feita uma análise de como certos mandatos sociais aparecem dirigidos às mulheres a fim de manter o status quo dos costumes tradicionais que sujeitavam as mulheres à esfera doméstica, ao cuidado dos filhos e aos afazeres domésticos, tudo isso materializado na instituição do casamento. Para isso, será trabalhado um corpus de filmes realizados nas décadas de 30 e 40 onde, aparentemente, as mulheres que os protagonizam encarnam de alguma forma rebeliões contra o modelo vigente, mas a história e o formato cinematográfico se encarregam de recolocá-los. no lugar tradicional da esposa submissa.

Palavras chave: Cinema - Mulher - Gênero - Estereótipos - Classe média - Heroína - filme ingênuo - Rebelião - Sociedade.

[Las traducciones de los abstracts fueron supervisadas por el autor de cada artículo] 